\title{
A hora e o lugar das Ordens Sufis na tradição islâmica
}

\section{The Time and Place of the Sufi Orders in the Islamic Tradition}

\author{
Mateus Soares de Azevedo ${ }^{1}$ \\ Investigador independiente (Brasil)
}

Recibido: 25-01-19

Aprobado: 28-02-19

\section{Resumo}

O que é o Sufismo? Em que ele acredita? O que ele pratica? É ele uma vertente mística do Islã para alguns poucos, ou uma via aberta a muitos? O que são as confrarias ou ordens sufis? Qual a sua natureza e sua razão de ser? Qual a sua origem e seu desenvolvimento histórico? São elas "iniciáticas" e destinadas a uma elite espiritual, ou "populares" e acessíveis em princípio a todos os fieis? Estas são algumas das questões que este ensaio busca responder.

Palavras-chave: Sufismo, Espiritualidade, Pacto da Árvore, Gnosticismo, Esoterismo.

\begin{abstract}
What is Sufism? In what does it believe? What are its main practices? Is it a mystical strand of Islam for a few, or a way open to many? What are the Sufi orders? What are their nature and reason for being? What are their origin and historical development? Are they "initiatic" and aimed at a spiritual elite, or are the Sufi Orders "popular" and accessible in principle to all believers? These are some of the questions that this essay seeks to answer.
\end{abstract}

Key-words: Sufism, Spirituality, Tree Pact, Gnosticism, Esotericism.

\footnotetext{
${ }^{1}$ (mateusaz@hotmail.com) Islamólogo e esoterismólogo brasileiro de trânsito internacional, autor de Men of a Single Book: fundamentalism in Islam, Christianity, and modern thought (EUA, 2010); A Inteligência da Fé; Cristianismo, Islã, Judaísmo (Rio de Janeiro, 2006); e Mística Islâmica (Petrópolis, 2002), entre outros livros.
} 
O Sufismo é o protótipo da espiritualidade no Islã; é a dimensão simultaneamente místico-devocional e esotérico-sapiencial da tradição muçulmana, corrente que existe desde os primórdios da religião, no século VII, ainda que o termo 'Sufismo' não fosse corrente então. Vale lembrar aqui, com Frithjof Schuon, que toda mística "resulta da tendência ao aprofundamento, à experiência interior; ela é 'sobrenaturalmente natural' ao homem, (...) corresponde a uma necessidade inata e se encontra em toda parte onde há uma religião, o legalismo desta última não podendo satisfazer a todas as aspirações."2

Uma característica saliente do Sufismo é a preparação de seus adeptos para o chamado "grande jihad" (jihad al-akbar) de que falou o Profeta Maomé. Ou seja, não o combate exterior ou convencional contra o outro, mas a luta contra si mesmo, contra as ilusões e o egoísmo quase natural ao ser humano. Isso significa dizer que visa não apenas "salvar" a alma do fiel ao termo da existência, como as religiões tradicionalmente propugnam, mas também purificá-la e, em última instância, "transformá-la", aqui e agora. ${ }^{3}$ Em outras palavras, na tradição islâmica, aquele que almeja purificar, transformar e enobrecer seu caráter segue preferencialmente o "reto caminho" (sirat almustaqim) do Sufismo.

Os mestres sufis que ensinam este método de transformação pessoal se vinculam a uma linhagem que retrocede ao próprio Profeta Maomé. Pois as origens do Sufismo remontam à sabedoria e intensa espiritualidade que havia em torno do Profeta e de seus discípulos mais próximos - algo que podemos imaginar como análogo ao ambiente em torno de Jesus e dos Apóstolos.

O advento de uma nova Revelação religiosa faz com que os padrões espirituais de uma dada civilização sejam incorporados ou absorvidos de maneiras diversas e em graus de comprometimento variados, de acordo com o perfil ou o tipo humano que é alcançado pela nova Revelação. A "fluidez original" desta última, no dizer do autor norte-americano Mark Perry, contudo, só sobrevive entre aqueles homens e mulheres de mentalidade mais contemplativa. Ademais, esta "essência fluida da religião" é preservada e transmitida de modo reservado e eventualmente apenas de modo oral, não fixado por escrito, de geração em geração, assim se perpetuando ao longo dos séculos. O Corão, a este respeito, refere-se àqueles que "adoram e temem a Deus em segredo".

O ímpeto original daquilo que séculos mais tarde passou a ser denominado de "Sufismo" é atribuído por muitos mestres sufis ao "Pacto de Hudaybiyah", ou "Pacto da Árvore" (no ano 628 DC). Foi então que, num momento particularmente

${ }^{2}$ Frithjof Schuon: "Enigma e mensagem de um esoterismo". In: Nos Caminhos da Religião Perene, p. 39. Tradução de Alberto V. Queiroz. São José dos Campos, Brasil, 2015.

3 “'A natureza específica do esoterismo é 'transformar' o homem, em vez de somente o 'salvar'; ou, antes, o esoterismo salva o homem transformando-o, e o transforma salvando-o.” (Schuon: Nos Caminhos da Religião Perene, p. 38.)

Araucaria. Revista Iberoamericana de Filosofia, Política, Humanidades y Relaciones Internacionales, año $21, \mathrm{n}^{\circ} 41$ Primer semestre de 2019. Pp. 395-414. ISSN 1575-6823 e-ISSN 2340-2199 doi: 10.12795/araucaria.2019.i41.19 
grave e decisivo da história do Islã, o Profeta Maomé fez um pacto com seus companheiros. Sob a sombra de um pé de acácia, no deserto da Península Arábica, eles se comprometeram a dedicar suas vidas e seus bens na causa de Deus.

Este pacto é mencionado no Corão (Sura 48, da "Vitória"), enfatizando que a mão de Deus pairou sobre a mão de Maomé quando ele a impôs sobre a dos seguidores. É esta mesma passagem corânica que, em nossos dias, compõe o "juramento iniciático" da maioria das confrarias, juramento este que vincula os iniciados a seu próprio mestre, este ao mestre dele, e assim sucessivamente através da Silsilá (a "árvore genealógica" dos mestres sufis) que remonta até o próprio Profeta.

O Sufismo engloba de fato uma gama variada de doutrinas, métodos e experiências, cuja latitude abrange desde cumes da espiritualidade sapiencial e devocional até híbridos sentimentais ou passionais de esoterismo e exoterismo, com diversos graus de voluntarismo, devocionalismo e gnose no meio.

Do ponto de vista puramente espiritual, o pacto dos Companheiros com o Profeta à sombra do pé de acácia no distante século VII constitui um momento crucial na história do Islã - mas isso não de um ponto de vista social ou político, mas em termos puramente espirituais. Foi esta corrente contemplativa que vem desde o Profeta e seus discípulos mais chegados que o Sufismo tem preservado ao longo dos séculos. A seiva sacra deste "Pacto da Árvore" anima a vida do Islã de uma maneira misteriosa, demonstrando que o que é "grande" espiritualmente falando pode ser "pequeno" no mundo ou temporalmente, e vice-versa, o que significa que o que é mais vital espiritualmente é quase sempre o que está mais oculto e só revela sua verdadeira importância e impacto algum tempo depois.

*

Mas, a despeito de a dimensão contemplativa e mística existir desde os primórdios do Islã, foi somente a partir da Idade Média que confrarias sufis (em árabe: sing. tarica) / plural turuq) se estabeleceram no mundo muçulmano. A razão deste acontecimento simultaneamente providencial e histórico foi preservar e desenvolver as doutrinas e práticas contemplativas da religião, com suas técnicas e seus métodos comprovados pela experiência centenária, colocando este patrimônio ao alcance daqueles fieis de perfil mais devocional ou "gnóstico" 4 -- sendo que estas duas categorias, a devocional ou "bháktica", de um lado, e a "gnóstica" ou "jnânica", de outro, mesclam-se no mais das vezes -, interessados em aprofundar sua relação pessoal e direta com Deus. A motivação para a fundação dessas fraternidades sufis também inclui a criação de uma ambiência material, psicológica e estética favorável ao trabalho interior.

\footnotetext{
4 "Gnóstico" aqui não tem nenhuma relação coma heresia gnosticista dos primeiros tempos do Cristianismo; a referência é ao termo de origem grega que significa puramente "conhecimento (espiritual).
} 
As ordens místicas surgiram por toda extensão de Dar al-Islam a partir dos séculos XII e XIII, e desde então, pelos oito séculos que se seguiram até nossos dias, elas têm exercido influência marcante e decisiva em sua vida espiritual e cultural. Exteriormente, ou extrinsecamente, tais ordens são tão distintas entre elas como o são as ordens do Catolicismo (franciscanos, beneditinos, dominicanos, etc.), cada qual enfatizando aspectos diversos da espiritualidade, mas, no essencial, ou intrinsecamente, elas são convergentes, como veremos a seguir.

Aliás, muçulmanos e cristãos compartilham todo um universo de crenças, valores, santuários, peregrinações e figuras santas. Nenhuma corrente ou escola do mundo semita-monoteísta-abraâmico supera o Sufismo neste compartilhamento que transcende fronteiras religiosas. Alguns sufis foram mesmo identificados com a benção, ou a baraca, de profetas e santos anteriores ao advento do Islã. Deste modo, há sufis que reivindicam uma vinculação mística com Saydna Aissa (Jesus Cristo); este foi o caso do cheique Al-Alawi (século XX). ${ }^{5}$ Outros sufis têm sido Ibrahimi (identificados ao profeta Abraão), Mariyamiyah (espiritualmente associados à Virgem Maria), ou "eliáticos" (Profeta Elias).

O Sufismo é, assim, plural, e oferece múltiplas possibilidades no campo do sagrado, possibilidades estas manifestadas pelas diferentes confrarias. Ele não possui uma autoridade teológica suprema e única; cada tarica exerce sua autonomia dentro dos parâmetros gerais dados pelo Corão e o exemplo do Profeta (Sunna). O Sufismo não é indiferente às leis e aos ritos do Islã; pelo contrário, ele se apóia sobre a Escritura e a Sunna.

Islã e Sufismo estão inextricavelmente entrelaçados; a Sharia deve ser cumprida por todos os muçulmanos; mas o Sufismo é vocacional, não compulsório.

Longe de constituírem fenômenos marginais ou secundários, as confrarias sufis estão no centro da mensagem espiritual e da cultura do Islã. Hoje, ademais, elas oferecem remédio eficaz contra o radicalismo políticoreligioso e o fanatismo militante que irromperam em certos setores de Dar el-Islam-- extravagâncias que ganharam uma projeção desproporcional muito recentemente, a partir das últimas décadas do século $\mathrm{XX}$, muito em razão da cobertura espetaculosa de meios de comunicação.

Outro aspecto singular das ordens sufis é que elas não pedem a seus postulantes que se retirem ou se separem do mundo, pois propõem a possibilidade de seguir uma via espiritual em meio aos afazeres correntes e à vida profissional e familiar. Paradoxalmente, em uma religião como o Islã, que rejeita em grande medida o ascetismo, o Sufismo é abertamente favorável a práticas ascéticas,

\footnotetext{
5 Ver a respeito a biografia do xeique Al-Alawi escrita por Martin Lings, A Sufi Saint of the twentieth Century (Cambridge, 1993).
} 
como vigílias noturnas, retiros, orações supra-rogatórias, exercícios espirituais, etc. E não só isso, pois o Sufismo opera também com a música e a dança, manifestações que, mesmo não sendo explicitamente proibidas pelo Corão, são reprovadas pelos ulemás, autoridades na lei islâmica (Sharia). ${ }^{6}$

$*$

Um aspecto à primeira vista paradoxal do Sufismo e de suas confrarias, presentes em toda a sociedade muçulmana, da China e Índia ao Marrocos, é justamente a sua enorme difusão por todos os extratos sociais. Geralmente se aceita que a dimensão esotérica de uma determinada tradição religiosa é necessariamente reservada, sendo restrita a uma elite intelectual e espiritual. Este era o entendimento do grande metafísico francês René Guénon (18861951), pelo menos se entendido literalmente. Ora, o Sufismo reivindica constituir esta dimensão para o Islã, mas ele está longe de ser restrito a uma elite; pelo contrário, o Sufismo chega mesmo a ser "popular" e está difundido por todas as camadas sociais. Como então explicar este paradoxo?

Ora, a opinião de que o esoterismo se definiria única e exclusivamente por uma doutrina metafísica integral e por uma práxis espiritual afeita somente a uma minoria contemplativa, denota, explica Frithjof Schuon, uma concepção de esoterismo que é "demasiado sistemática e de fato irrealista, mas ela manifesta uma possibilidade que está na natureza das coisas, o que quer dizer que um esoterismo vulgarizado tira sua justificação de certa eficácia”.?

Schuon adverte, contudo, que um esoterismo "ampliado", como o Sufismo, sempre "contém em algum setor a sapiência autêntica; ele tem segredos, mas somente em seu 'núcleo', não em sua 'casca'; ele não é ele próprio a sapiência, mas, graças ao seu sistema de graus de interioridade, a natureza específica do puro esoterismo é salva, ali onde ela pode e deve se afirmar." 8

Comparando o Sufismo com o Cristianismo primitivo, Schuon explica que este último constituiu "um esoterismo em virtude de sua perspectiva de 'interioridade' - em detrimento da exterioridade, donde sua heterogeneidade do ponto de vista da Lei de Moisés -, e ele se difundia pela pregação". O Sufismo é semelhante ao Cristianismo neste aspecto, pois ele "é esotérico em virtude de sua perspectiva de 'via espiritual', portanto de 'realização', de 'transmutação'; perspectiva esta que é alheia à Lei exotérica." 9

A mística islâmica e o Cristianismo possuem ambos seus mistérios e seus segredos, não obstante há nos dois casos uma mensagem que se dirige "a muitos", se não "a todos". Portanto, quer se queira, quer não, uma "propaganda"

\footnotetext{
${ }^{6}$ Ver a respeito deste ponto o esclarecedor artigo de Jean-Louis Michon "Sacred Music and Dance in Islam". In: ISLAMIC SPIRITUALITY: Manifestations (Ed. S. H. Nasr), p. 469 (EUA, Crossroads, 1997).

${ }^{7}$ Frithjof Schuon: Nos Caminhos da Religião Perene, p. 40 (disponível eletronicamente em: fschuon.net).

${ }^{8}$ Idem, p. 40.

${ }^{9}$ Schuon: Nos Caminhos da Religião Perene, p. 40.
} 
iniciática, por assim dizer, existe de fato e vem existindo desde as origens do Sufismo. No século XIX, lembra Schuon, um xeique sufi, Al-Baddî, iniciou na tarica Tijâniyah uma tribo berbere inteira -- exemplo de que o "elitismo iniciático" não prepondera senão nos casos em que ele se impõe. Vale notar igualmente a este respeito que o Islã se difundiu na Índia muito mais pela ação "evangelizadora" das ordens sufis do que por qualquer outro fator.

Os chamados "Cinco Pilares" do Islã constituem o ponto de partida teológico e espiritual para o trabalho das confrarias sufis. São eles: a Fé, a oração, o jejum, o dízimo e a peregrinação. Na formulação de William Stoddart: ${ }^{10}$

1. a Fé: Não há deus senão o único Deus.

2. a Oração: cinco vezes ao dia.

3. o Jejum: no mês do Ramadã.

4. o Dízimo (Zakat): "aos pobres, órfãos e viúvas".

5. Peregrinação (Hajj): à "pedra negra" abraâmica na Caaba, em Meca.

Vale ressaltar que o Jihad é visto por alguns como o "sexto pilar" do Islã: segundo o Profeta Maomé, a luta contra os idólatras é o "pequeno jihad"; a luta contra o próprio ego constitui o "grande jihad".

O Sufismo outra coisa não é que este "grande Jihad", que constitui igualmente o principal "trabalho" espiritual das confrarias.

$*$

As origens do Sufismo e de suas confrarias remontam ao Profeta. Maomé foi, assim, o revelador e o mediador de duas correntes tradicionais relativamente diferentes, mas ao mesmo tempo interligadas entre si e divergentes: uma legal, comum e obrigatória [o Islã], a outra ascética, particular e vocacional [o Sufismo], como observou Frithjof Schuon em Nos Caminhos da Religião Perene. ${ }^{11}$ A adesão a uma ordem sufi não é compulsória para os muçulmanos, mas a adesão ao Islã é condição sine qua non para acesso a ela. Não há Sufismo sem Islã.

Confrarias sufis estão presentes em todo o mundo islâmico, do Marrocos (no Magrebe) à Indonésia (na Ásia). São centenas de irmandades em operação, a começar da Qadirya, estabelecida sobre a mensagem do mestre sufi Abdul Qadir al-Jilani em Bagdá, no séc. XII. Abdul Qadir foi o primeiro mestre a trazer para a arena pública os métodos e as doutrinas sufis, e fundou a primeira comunidade de adeptos, como veremos adiante.

Ordens místicas muçulmanas se difundiram na África negra, no Marrocos, no Egito, mas também na Índia, no Paquistão, na Turquia. E igualmente em áreas outrora sob domínio soviético, como Bósnia, Albânia, e nas exrepúblicas do Cáucaso (Chechênia, Azerbaijão, etc). Algumas irmandades se

${ }^{10} \mathrm{Cf}$. What does Islam mean in today's world? (World Wisdom, EUA, 2011.)

${ }^{11}$ P. 38. 
estabeleceram também no mundo ocidental. Por seu foco na espiritualidade e na virtude pessoal; por sua presença internacional; por sua postura elevada; sua abertura para outras religiões, o Sufismo se tornou hoje relevante para um melhor entendimento da presença do Islã no mundo contemporâneo.

As confrarias sufis têm se constituído no melhor antídoto contra o surto de intolerância e violência político-religiosa corporificado naquilo que a imprensa ocidental chama de "fundamentalismo islâmico". Contudo, a maioria dos autênticos fundamentalistas, como os wahabitas sauditas, aqueles que têm uma visão mais literalista e formalista da religião, em geral não acreditam na eficácia desta violência, nem recorrem necessariamente a ela. "Fundamentalista" se tornou um termo fácil, um pouco como num passado recente "'xiita" equivocadamente havia se tornado sinônimo de "radical".

Além de ser o melhor remédio contra o extremismo e a intolerância, o Sufismo oferece também o melhor patrimônio espiritual e cultural do Islã, como resposta aos desafios do materialismo e do ceticismo modernos. O Sufismo constitui, assim, uma importante porta de entrada ao Islã no Ocidente.

*

Pode-se também apresentar o patrimônio das confrarias místicas ou esotéricas por intermédio da visão sufi de Jihad. Jihad outra coisa não é que o esforço na causa da fé, esforço simultaneamente contemplativo e interior, de um lado, e esforço social e ideológico, de outro - um combate, em suma, tanto esotérico como exotérico.

O jihad é uma realidade universal, toda civilização o possui, não só o Islã. $\mathrm{Na}$ tradição cristã, tivemos as Cruzadas, de um lado, e o "combate espiritual" e interior, como pregado por Santo Inácio de Loyola, de outro. No Hinduísmo, um de seus livros fundamentais, o Bhagavad-Gita, trata também dos dois jihads, exotérico ou exterior um, esotérico e interior outro. O Islã simplesmente expressa esta realidade universal de modo claro e explícito: o fiel tem o dever de combater o mundo e o ego.

Não se deve confundir esta perspectiva tradicional em relação ao jihad com a visão de grupos extremistas modernos islâmicos que reivindicam o mesmo conceito; estas facções substituem a paz, harmonia, senso de justiça e respeito às injunções da Lei pelo ódio cego, o espírito de vingança, o ressentimento, a fúria e a agitação constante, vícios que caracterizam o entendimento distorcido de jihad.

Outro aspecto importante do problema é o seguinte: em sua fúria em nome do Islã, esses grupos extremistas se voltam contra as demais religiões, fechando-se num exclusivismo e numa intolerância em um momento histórico em que o entendimento e a concertação entre as grandes tradições religiosas são mais necessários do que nunca.

* 


\section{Origens e razão de ser das ordens sufis}

Hoje, ninguém desconhece que as nações islâmicas são agitadas pelo extremismo político; ainda assim, a mensagem fundamental de serenidade do Islã persiste, especialmente nas confrarias sufis. As turuq são as principais responsáveis pela preservação do patrimônio espiritual e contemplativo da religião.

Nos primórdios do Islã, grosso modo do século VII ao XI, os sufis se reuniam em pequenos grupos em torno de um mestre que, em geral, pregava e ensinava nas mesquitas e madrassas (escolas corânicas). Gradualmente, com a maior difusão da religião por um vasto território e com a maior complexidade social, étnica e cultural que se seguiu à fulminante expansão do Islã, que em poucas décadas difundiu-se da Península Ibérica, no oeste da Europa, à Índia e China, as ordens sufis foram se organizando e definindo suas práticas, costumes e regras.

Desde o século XII que ordens irmandades sufis se estabeleceram e se difundiram, umas de caráter mais local ou regional, outras mais internacionalizadas, cada qual enfatizando este ou aquele aspecto da via espiritual, adaptando-se aos diversos territórios culturais, linguísticos e étnicos do vasto mundo muçulmano.

Essas confrarias se formaram com o intuito de preservar, proteger e dar continuidade às doutrinas e aos métodos contemplativos da espiritualidade islâmica. Doutrinas e métodos estes que poderiam se diluir, corromper ou mesmo se perder completamente devido à mera passagem do tempo e à crescente diversificação e massificação das sociedades islâmicas, passados cinco séculos do advento da Revelação corânica (no século VII).

Assim, a razão mais importante para o estabelecimento das turuq reside na demanda por "estruturas" e instituições que marcassem um "campo" ou um "território" para a interioridade. A criação das ordens sufis possibilitou aos contemplativos muçulmanos praticarem um contato mais próximo, regular e intenso com o mundo do Espírito do que aquele oferecido pela piedade convencional.

As turuq, assim, garantiram a manutenção, atualização e continuidade do depósito de métodos iniciáticos no seio do Islã. A razão de ser dessas ordens místico-esotéricas é propiciar a continuidade do Sufismo através dos tempos. Elas são as guardiãs dos ensinamentos e técnicas esotéricos do Islã, com a verdade e a beleza da mensagem corânica se consolidando por meio das turuq. Em particular, as confrarias se estabeleceram para serem as depositárias do Dhikr e de seus métodos de utilização (mais sobre este tópico a seguir, na seção dedicada aos "métodos iniciáticos"). 
A razão da existência das Ordens está também relacionada à custódia e difusão dos ensinamentos maometanos sobre a importância das virtudes na vida espiritual, especialmente a humildade e a generosidade. Pois não é repetindo fórmulas de maneira meramente mecânica, acreditam os mestres sufis, que o adepto amadurecerá espiritualmente. Segundo a perspectiva sufi, as virtudes são tanto um fruto das práticas contemplativas, especialmente do Dhikr, como devem coadjuvá-lo.

Há que levar em conta também que, sem as turuq, provavelmente métodos esotéricos como as danças extáticas de algumas ordens não teriam resistido à passagem dos tempos e à incompreensão das autoridades convencionais da religião. Em suma, as confrarias sufis viram a luz do dia para serem as principais depositárias da via espiritual no Islã.

*

\section{Métodos iniciáticos utilizados pelas confrarias sufis}

O Dhikr - O principal método de realização espiritual praticado pelas ordens sufis é o Dhikr, a "Lembrança" ou "Recordação" de Deus. Dito assim pode parecer algo vago e abstrato; qualquer coisa pode indicar esta "lembrança". Mas, num contexto sufi, o Dhikr indica um método particular de concentração meditativa, que encontra ademais equivalentes em outras grandes tradições espirituais da humanidade. Entre elas, o japa-yoga hindu, por exemplo (yoga é "caminho" ou "via" em sânscrito, e japa significa repetição ritual de um nome ou fórmula sacros). Assim, a invocação sufi pode também ser aproximada do conhecido "mantra" que vem da Índia e é utilizado no contexto do japa-yoga acima referido. Na tradição cristã, o equivalente do Dhikr é o que se chama de invocação ou oração jaculatória.

Na vida das confrarias, o Dhikr é tudo; não há Sufismo operativo sem ele. O Dhikr é cerne da vida espiritual das confrarias, é uma prática freqüente, regular e rigorosa.

Para os mestres sufis, sem a "Lembrança de Deus" o homem está perdido. Mesmo os demais métodos de concentração utilizados pelas confrarias, como o retiro espiritual, as vigílias noturnas, o jejum ou até a dança ritual, todos giram em torno do eixo do Dhikr.

E sua razão de ser e, por consequência, das demais práticas a ele vinculadas, é engendrar a "Lembrança do Eterno" e a superação interior e contemplativa do temporal; ou a Recordação de Deus e o esquecimento de si. Extinção do ego e iluminação interior.

De um ponto de vista mais profundo, poderíamos dizer que o Dhikr é a “oração das orações", ou "a rainha das orações", porque se as preces canônicas 
(como o Pai-Nosso no Cristianismo e as cinco orações diárias no Islã) têm o homem como ponto de partida, o Dhikr se origina no Eterno e retorna ao Eterno. Nele, a origem da oração é a "centelha divina que existe no coração humano", como dizia Mestre Eckhart; esta "centelha” é o Deus imanente, o divino "que está mais próximo do homem que sua veia jugular", como expressa um hadith. Assim, no Dhikr, se Deus é o Objeto da oração, Ele é também o Sujeito imanente dela.

"A oração não é somente algo humano", notou o autor francês Patrick Laude, pois ela "pode descer do Céu como um dom." Neste caso, "ela manifesta uma necessidade divina". "A oração que não é mais uma petição ou uma expressão individual, emerge do mais profundo da alma (...) a invocação é então a 'prece de Deus.", 12

A Iniciação - O Sufismo é uma "disciplina iniciática", posto que sua condição sine qua non é a "iniciação" (aos mistérios divinos). Assim, antes de ter acesso ao Dhikr e demais métodos "iniciáticos", os quais não estão acessíveis ao crente comum, o aspirante a ingressar em uma tarica deve passar por um rito de iniciação.

Este rito assume a forma de um "pacto" entre o aspirante e o mestre espiritual (xeique) ou seu representante (moqqadem) - cujo modelo remonta ao "Pacto de Hudaybiyah", de 628 DC, selado com o Profeta, como vimos anteriormente. Os pré-requisitos básicos são a qualificação espiritual, intelectual e moral do postulante e a ortodoxia da confraria, que zela pela transmissão regular do influxo espiritual (baraca) que remete ao próprio Profeta. Deste modo, cada ordem sufi possui a sua Silsilá, que é uma espécie de árvore genealógica de todos os seus mestres ao longo da história, dos dias de hoje à época do Profeta.

A iniciação é como um "segundo nascimento"; primeiramente o homem nasce "na carne" quando vem ao mundo, depois ele nasce espiritualmente pela iniciação. O sufi professo é, assim, "duas vezes nascido".

$\mathrm{O}$ dhikr visa antes de tudo a levar o iniciado a se esquecer de si e do mundo, para se concentrar em Deus. Esta operação envolve todo o seu ser, o homem por inteiro, engajando portanto sua vontade, seu sentimento e seu conhecimento.

No contexto dos métodos operativos utilizados pelas confrarias esotéricas do Islã, o dhikr é praticado em termos absolutamente regulares e metódicos. Ou seja, o iniciado tem na invocação a sua principal prática de realização.

Na verdade, a meta do Sufismo é tornar esta Lembrança por meio da repetição ritual do Nome divino uma espécie de "segunda natureza" para o iniciado. Como disse uma vez São Paulo apóstolo, "orai sem cessar e não desfalecei". Isto significa que, em princípio, a invocação deve ter como norte a perpetuidade.

${ }^{12}$ Cf. Patrick Laude: "L ‘Appel du Coeur”, p.71 (Revista Ultreïa, França, vol. 6, Hiver 2016.) 
O retiro espiritual - Com o intuito de fixar o Nome na consciência do adepto, mestres sufis têm o costume de colocar o iniciado em khalua (retiro espiritual) - como se verifica nas turuq Alawiya, Darqawiya e Shadhiliya. Esta reclusão pode durar horas, dias ou semanas; Frithjof Schuon relata que o xeique Alawi manteve uma vez um discípulo em retiro por nove meses! ${ }^{13}$

Isto significa que o membro de uma tarica se coloca sob a orientação do xeique em uma azóia (capela sufi), na qual há aposentos específicos para este retiro. Lá, a principal atividade do adepto é a invocação do Nome Divino, que ele pratica horas a fio, isolado em sua cela, praticamente sem contato com o mundo exterior. Em geral apenas o xeique ou seu representante acompanham o retirante em seu período de isolamento.

Há também confrarias que têm na khalua um método regular, que é posto em prática por seus seguidores mensalmente, ou em intervalos maiores, mas sempre algumas vezes por ano.

Os retiros espirituais, sejam eles longos ou curtos, geralmente começam com as orações canônicas e podem se encerrar, após o dhikr, com uma oração individual livre, na qual o adepto se dirige livremente a Deus agradecendo por ter lhe concedido paciência e constância para levar a bom termo o seu exercício espiritual.

As danças sacras - Outro método de concentração espiritual utilizado por algumas confrarias é a dança extática. Por "dança" não se entenda aqui a mesma coisa que se entende no Ocidente moderno, pois não se trata em absoluto de uma 'apresentação artística'. Este é o caso notadamente da ordem turca Mevlevi, célebre pela dança ritual verdadeiramente espetacular de seus dervixes. Algum tipo de dança contemplativa também é praticada por outras ordens, como por exemplo a Alawiya ou a Darqawiya - sendo que, nestas últimas, os movimentos têm formato e exibem movimentos corporais distintos. Enquanto os mevlevis giram individualmente em círculos em torno do próprio eixo corporal, os alawis e darqawis se movem em grupo e dão passos para a frente e para o lado.

O objetivo comum de todas esses movimentos extáticos é levar o homem a um estado de maior proximidade do Divino, a uma concentração espiritual intensa.

Aparentemente o primeiro mestre sufi a se valer da dança como meio de concentração espiritual foi Jalal adin-Rûmi (séc. XIII). Segundo uma legenda popular, Rûmi contemplou esta dança celestial numa visão do Paraíso. De volta ao nosso mundo, o do tempo, do espaço e do número, Rûmi teve a inspiração para reproduzir aqui a dança sacra que contemplou na eternidade.

\footnotetext{
${ }^{13}$ Cf. De tout Coeur et en l'esprit, p. 62 (Paris, L'Harmattan, 2017).
} 
Em épocas de maior intolerância e mesmo de perseguição, seja de parte das autoridades políticas seculares, seja daquelas da religião convencional exotérica, tais "danças" assumiam uma feição "folclórica" ou "cultural", com o intuito de dissimular ante possíveis censores seus intentos mais profundos - isso sucedeu frequentemente com os mevlevis turcos, especialmente no enfrentamento do secularismo tirânico de Ataturk e seguidores, na primeira metade do século XX.

O majalis é outra prática comum a todas as ordens, do Oriente e do Ocidente, sunitas e xiitas. Majalis é a "assembléia" de oração dos iniciados. Nestas ocasiões, os sufis se reúnem para fazer juntos as orações canônicas, rezarem o rosário islâmico (o wird, que é composto de três orações curtas). Nestas assembléias, há também em geral leitura dos textos reservados produzidos pelos mestres da tarica e sessões conjuntas de invocação do nome de Allâh.

*

Algumas das principais irmandades sufis são as seguintes.

\section{Qadiyria, a tarica pioneira}

Abdel Qadir al-Jilani (1077-1166), nascido em Jilan, ao norte de Bagdá, onde viveu praticamente toda a sua existência, foi o mentor da primeira ordem sufi, que é também a mais universalmente difundida das turuq. Abdel Qadir se notabilizou por ter sido o primeiro mestre a trazer para a arena pública as doutrinas e os métodos contemplativos do Islã e fundar a primeira comunidade de adeptos.

Abdel Qadir foi um líder carismático, com a personalidade agregadora e generosa de um grande santo, daqueles capazes de atrair para si até mesmo céticos e adeptos de outras religiões que não o Islã. Ele foi simultaneamente um guia de almas extremamente perspicaz e um professor popular, capaz de explicar as doutrinas sufis em termos acessíveis à generalidade dos fieis.

Antes de se tornar um líder popular, Abdel Qadir estudou nas madrassas de Bagdá e, depois, viveu onze anos isolado como eremita. Foi somente após este período de purificação e oração que ele re-emergiu como pregador místico e religioso. Relatos contemporâneos mostram como ele era capaz de manter multidões fascinadas com suas palavras. De fato, segundo o islamólogo americano Victor Danner, com Abdel al-Qadir a história da mística islâmica recebe um novo e vigoroso elemento, pois é então que os chefes sufis começam a se dirigir às massas muçulmanas.

A organização e reunião de fieis de perfil místico e/ou esotérico em uma irmandade atendiam à necessidade providencial de demarcar e proteger 
o legado contemplativo da tradição islâmica, dado que, numa civilização mundial como a muçulmana, os tipos humanos são bastante distintos, dos mais fundamentalistas, literalistas e puritanos, aos mais filosóficos, místicos e esotéricos, cada tipo demandando uma abordagem específica. A questão que se poderia colocar aqui envolve a continuidade e resiliência da dimensão mística da religião caso as confrarias não tivessem fixado determinadas "fronteiras" e territórios para aqueles fieis de conformação contemplativa. Neste sentido, o estabelecimento de confrarias foi providencial.

Tanto houve um caráter de inevitabilidade, por assim dizer, que azóias ("capelas sufis") daquela que foi a primeira tarica organizada se espalharam do Oriente ao Ocidente, através dos Bálcãs, Rússia, Palestina, China, África e Índia. Na Índia, a Qadiyria teve grande êxito, já no século XVI, atraindo até o herdeiro do trono mogol, Dara Shukoh, que recebeu sua iniciação nela. Dara Shukoh era filho do imperador Shah Jahan (o responsável pela construção do Taj Mahal), e ficou célebre por ter traduzido os "Upanishades", e por ter identificado esta escritura hindu com o "livro oculto", ou "bem-guardado", ao qual o Corão alude na Sura 56:78.

Seja como for, não queremos com isso avançar a tese de que as confrarias se formaram graças a uma decisão pré-estudada ou planejada, pois as origens do Sufismo são absolutamente "orgânicas" e corânicas, e remontam à intensa espiritualidade que havia em torno do Profeta Maomé e de seus discípulos mais próximos.

\section{Shadhilia, a tarica marroquina que ganhou o mundo}

Uma das grandes manifestações de renovação espiritual e intelectual, e, consequentemente, também social, no mundo islâmico ocorreu no extremo ocidente de seu território, o Magrebe (que inclui Marrocos, Argélia, Tunísia, Líbia e a Península Ibérica), com o advento da figura maior do xeique Abul Hassan A1Shadhili (1195-1258). A tarica Shadhilia foi estabelecida em meados do século XIII, e logo prosperou por toda a região magrebina, e mesmo além dela.

A abordagem do xeique Shadhili é sapiencial ou gnóstica, isto é, a ênfase de seu método de realização não está posta num devocionalismo emocional, nem no ascetismo, tampouco num puritanismo moralista. Ele foi um intelectual visionário, não um acadêmico livresco e pedante; alguém devotado à realização pessoal daquilo que leu e compreendeu. A partir do principio básico da fé islâmica de que Deus é um Ser único, absoluto e eterno, Shadhili pregava a concentração de seus discípulos na realidade única de Deus por meio da prática constante do Dhikr, a "Recordação de Deus", exercício diário composto de oração e meditação, com eventuais jejuns e retiros. 
O principio islâmico da unidade e unicidade de Deus (tawhid) implicava para ele na unificação pessoal do iniciado de sua tarica, e este proceso de centralização do indivíduo provinha da prática constante do Dhikr. Em suma, a abordagem da tarica era "sapiencial", não voluntarista, nem sentimentalista.

Um aspecto à primeira vista surpreendente de seus ensinamentos estabelecia que o discípulo deveria ganhar a vida com seu próprio trabalho, honesto e bem realizado; todos os membros da tarica deveriam, assim, ter uma profissão ou uma ocupação no mundo, eles não deveriam se separar da sociedade na qual estavam inseridos, e é em meio às ocupações profissionais e familiares que o iniciado shadhilita deve praticar o método contemplativo.

Isso certamente implicava em profundo auto-domínio e no exercício das virtudes fundamentais, como a humildade em relação a si mesmo e a generosidade em face dos outros. Acarretava igualmente a consciência constante do erro implicado na ambição e na insaciabilidade mundanas. Ou seja, o iniciado shadhilita segue o "caminho do meio"; ele vive no mundo, mas não é dominado por ele.

Segundo Victor Danner ${ }^{14}$, o xeique Shadhili encarna como ninguém os ideais do Sufismo e deve ser considerado como uma expressão maior do chamado "Sufismo normativo", isto é, a mística "sóbria", isenta de eventuais "extravagâncias" e que não entra em confrontos desnecessários com a religião exotérica. Shadhili, assim, tipifica o mestre sufi através dos séculos.

A relevância espiritual e histórica da tarica Shadhilia é tamanha que sua influencia extrapolou, já no século XX, ou seja, sete séculos após sua fundação, as fronteiras do mundo islâmico, com o advento da obra do metafísico francês René Guénon (1886-1951), que foi filiado à azóia shadhili do Cairo durante a época em que ele viveu no Egito, entre 1930 e 1951.

A tarica, ademais, tem contribuições importantes para a literatura islâmica, especialmente com as obras de Ibn Ata'Allâh (Alexandria, 1257- Cairo, 1310). Ata'Allâh foi o terceiro grande mestre da tarica Shadhilia e o autor dos célebres "Aforismos Sufis" e do primeiro tratado sistemático sobre o principal método de realização espiritual dos sufis, o Dhikr ("Lembrança de Deus"), intitulado "A Chave da Salvação" (Miftâh al-Falah, no original árabe).

Os aforismos de Ibn Ata'Allâh ${ }^{15}$ foram ao longo do tempo sendo reconhecidos como uma obra-prima única da literatura islâmica, composição original que expõe em frases curtas e lapidares o cerne da sabedoria. É um dos grandes livros da espiritualidade universal, não apenas islâmica. A difusão e influência de suas obras foram talvez os principais fatores de popularização da tarica Shadhilia no Magrebe, Egito e outras áreas do mundo islâmico.

\footnotetext{
${ }^{14}$ Ver The Islamic Tradition (Warwick, New York, Amity House, 1988).

15 Há algumas traduções desta obra prima para línguas ocidentais, inclusive para o português (publicada por Ibrasa, em São Paulo), mas a mais reputada é a versão em inglês de Victor Danner, traduzida diretamente do árabe clássico e que leva o título de Sufi Aphorisms - Kitab Al-Hikam (Brill, 1997).
} 
Além disso, mais recentemente, alguns dos reitores da Universidade Al-Azhar no Cairo, principal centro intelectual do mundo islâmico, têm sido seguidores desta tarica, como Abdel Halim Mahmud, que conviveu com René Guénon no Cairo durante a primeira metade do século XX e escreveu um livro sobre o francês, Un Sufi d'Occident: René Guénon (Beirute, 2007).

\section{A tarica asiática Naqshbandiah}

A Naqshbandiah é uma das ordens místicas mais difundidas e influentes do mundo islâmico, com foco na Ásia central. Foi estabelecida em Bukhara (hoje no Uzbequistão), no século XIV, e até os dias de hoje exerce influência significativa na vida de muçulmanos de quatro continentes e dezenas de nações. No século XX, foi importante na resistência à ideologia ateísta e ao imperialismo soviético.

Seu fundador, Bahauddin Naqshband, mestre sufi nascido em 1318, pregava um estilo de vida simples e discreto; costumava ensinar que "aquilo que é aparente, é para o mundo; aquilo que está oculto, é para Deus".

Ele encorajava seus discípulos ganharem o pão de cada dia por meio de trabalho honesto; ou seja, eles deveriam viver a espiritualidade em meio aos afazeres do mundo, e não totalmente separados dele. Bahauddin mesmo deu o exemplo: por sete longos anos, ele trabalhou, como parte de seu treinamento sufi, como pastor de animais. Durante outros sete anos, ele trabalhou com conservação de estradas. O propósito de tais atividades era aprofundar as virtudes da paciência e da humildade; Bahauddin acreditava que a arrogância e a presunção enfraqueciam a fibra espiritual do sufi e diminuíam a estatura moral do homem.

O regimento espiritual da tarica Naqshbandi estava baseado na crença de que a meta da existência humana é ocupar-se da "Lembrança de Deus" tanto quanto possível. Um dos textos básicos da confraria instrui os adeptos a "aprender a jurisprudência islâmica e as tradições (hadith) do Profeta; não buscar a fama; não aceitar cargos na corte; não se mesclar com os governantes e poderosos; não ouvir muita música mística; não condenar a música mística; não casar com mulher que busca apenas conforto material". A companhia do sufi deve ser outro sufi; sua riqueza deve ser a pobreza; sua casa, a mesquita, e seu maior amigo, Deus.

Os naqshbandis chegaram à Índia no século XVI e transformaram o panorama religioso no subcontinente, ao mesmo tempo que a confraria recebeu um forte impulso, com o estabelecimento de azóias em muitas cidades do Império Mogol (muçulmano indiano). 
A tarica Naqshbandiyah reivindica que sua Silsilá (conceito sufi similar ao da "sucessão apostólica" católica) remonta ao primeiro califa e sucessor do Profeta Maomé, Abu Bakr. Esta reivindicação explica em parte o fato de que a confraria prega aderência e respeito à lei (Shariah) e à Sunna do Profeta (suas tradições). De par com tal característica, vale notar também que, diferentemente de ordens como a Shadhilia e a Qadiriyah, os naqshbandis procuram se imiscuir nos assuntos temporais, em particular procurando influenciar as classes dirigentes no sentido de maior entendimento e respeito pelas questões espirituais. "O rei é como a alma, e o povo como o corpo", dizia um dos chefes da tarica na Índia. "Se o rei se desvia, o povo rapidamente o seguirá neste caminho equivocado."

Hoje, a tarica Naqshbandi segue sendo uma das mais ativas e influentes confrarias místicas muçulmanas, com azóias estabelecidas em todo o mundo islâmico e mesmo no Ocidente.

\section{A ordem sufi indiana Chishtia}

A chishtia é a mais destacada ordem sufi do sul da Ásia desde a Idade Média. Seu nome deriva da cidade de Chisht, no Afeganistão. Um de seus grandes mestres foi Moinuddin Chishtī (1142-1236), místico, filósofo e erudito religioso de origem persa que se estabeleceu na Índia. Ele ficou conhecido por ter sido um dos primeiros líderes místicos do Islã a permitirem o uso de música em seus rituais. De fato, a utilização da música e do canto são elementos característicos do método chishtia.

A confraria tem sido a mais influente do subcontinente indiano há séculos, mas não ultrapassa suas fronteiras para outras áreas do mundo islâmico. Como ocorre com toda grande ordem, reivindica uma linhagem iniciática que remonta ao profeta Maomé,por intermédio do califa Ali $(+661)$ e de seu discípulo, o célebre sufi Hassan de Basra (+728).

Diferentemente de algumas outras ordens, os chishti almejam manter distância do poder temporal, e recomendam a seus adeptos não se envolver com assuntos de estado. Na Índia, os santuários Chishti são abertos a adeptos de outras fés e costumam atrair multidões em seus festivais.

Os ensinamentos de Khuâjah Mu'in al-Din (1141-1236), responsável pelo estabelecimento da tarica na Índia, se consolidaram como regras da via espiritual da confraria. Eles pregam a indiferença pelo dinheiro e o conforto material. Estipulam que os sufis não devem amaldiçoar a ninguém, nem se considerarem os autores de boas ações, as quais devem, ao contrário, serem atribuídas à Misericórdia Divina ou à intercessão do Profeta Maomé. Khuâjah ensinava também que seus discípulos deveriam de preferência se manter 
quietos e só falarem quando isso fosse absolutamente necessário; segundo ele, a lei islâmica torna ilegal tanto falar sem parar, como manter total silêncio, sendo que o caminho da virtude está no meio.

\section{A irmandade turca Mevlevia}

Os ensinamentos e a presença espiritual que deram origem e sustentam a tarica Mevlevia derivam da imensa figura do sábio e místico Jalal ad-Din Rûmi (1207-1273). Sua mensagem universalista transcende fronteiras teológicas e divisões sectárias e toca corações, independentemente de suas roupagens nacionais ou étnicas.

De fato, o mentor dos "Dervixes Rodopiantes" é um dos autores mais conhecidos no Ocidente hoje; suas principais obras são o "Masnavi", épico com cerca de 25 mil versos, e o "Divân", com 40 mil versos. A tarica se tornou mundialmente conhecida sobretudo por sua dança ritual. Mas esta "dança extática" não é senão um suporte para a "Lembrança de Deus" como praticada pelos sufis.

A tarica Mevlevia é até hoje influente especialmente na Turquia e nas antigas províncias do Império Otomano, como a Bósnia.

"A mensagem de sábios e santos como Rûmi”, observou Samuel Bendeck Sotillos, "constitui um antídoto à crescente ignorância e ódio que sitiam o mundo de hoje." 16

Já para a islamóloga alemã Annemarie Schimmel, "a cultura turca deve muito aos mevlevis; eles cultivaram a caligrafia e a música, assim como a poesia" (em "Sufism and spiritual life in Turkey").

A Mevlevia se tornou realmente consolidada na era otomana, a partir do século XIV, quando atraiu a atenção de sultões, alguns dos quais se tornaram adeptos da confraria. Neste período, e com as conquistas otomanas, os Mevlevis se difundiram pela Europa, especialmente pelos Bálcãs, o Oriente Médio e o Egito.

Com a queda do Império Otomano, o último império muçulmano da história, consequência de sua derrota na $1^{\mathrm{a}}$ Grande Guerra (1914-18), e a criação de um sistema republicano na Turquia, o novo autocrata, Mustafá Kemal, mais conhecido como Atatürk (o "pai dos turcos"), proibiu o funcionamento da tarica Mevlevia. Isto foi em 1925.

No período anterior à $1^{\mathrm{a}}$ Guerra Mundial, a tarica atraíra um enorme contingente de adeptos e contava com cerca de cem mil discípulos em todo o território otomano. Em 1925, como parte de seu desejo de criar um estado secular moderno e ocidentalizado na Turquia, Atatürk proibiu o funcionamento das ordens sufis e fechou suas azóias.

${ }^{16}$ Cf. revista Parabola, p. 111 (New York, Spring, 2018). 
As instituições vinculadas ao Sufismo também foram suspensas e suas dotações expropriadas; os abrigos e sanatórios sufis foram fechados e seus bens apreendidos; todos os títulos religiosos foram abolidos e os trajes sufis foram proibidos em vias públicas. Em 1937, Atatürk foi ainda mais longe, proibindo por lei qualquer forma de música tradicional, especialmente o uso do ney, a flauta de junco dos sufis.

Mas, tais perseguições não sufocaram totalmente as atividades da confraria, que seguiu existindo numa semi-clandestinidade até recentemente, provando assim que a mensagem de profundidade e beleza originalmente transmitida por Rûmi segue viva e relevante mesmo oito séculos depois que ele se foi deste mundo.

\section{Uma tarica xiita, a Nimatullahi,}

A Nimatullahi é a mais influente e difundida das confrarias xiitas; deriva dos ensinamentos de Shah Nimatullah, do séc. XIV. Vale notar aqui que os métodos sufis, tanto no mundo sunita, como no xiita, são bastante similares. Ambos enfatizam o Dhikr, a oração individual e comunitária, os retiros espirituais, e eventualmente a utilização ritual de música e dança.

Desde a revolução de 1979 no Irã, liderada pelo aiatolá Khomeini, que a tarica Nimatullahi enfrenta a hostilidade de um regime descrito por alguns como uma "tirania de clérigos", o qual vê no Sufismo um concorrente ao poder dos mulás. O último mestre Nimatullahi e outros dirigentes da ordem foram forçados a emigrar para o Ocidente, onde criaram centros sufis e atraíram seguidores, sobretudo na Europa e nos EUA.

A confraria tem como um de seus princípios não recusar orientação e guiamento a quem quer que lhe bata as portas, ensinando os postulantes de acordo com a capacidade de cada um.

Assim como no mundo sunita, houve na história da principal nação de orientação xiita, o Irã, períodos em que as autoridades religiosas exotéricas (os mulás, ou ulemás) se voltaram contra o Sufismo, numa disputa por legitimidade religiosa. Isto ocorreu, por exemplo, na época Safávida (séc. XVI a XVIII) e, mais recentemente, após a revolução khomeinista, que de início abriu guerra aberta contra os sufis. Mas, com o passar dos anos esta hostilidade foi sendo algo amainada, a despeito de estar longe de ter sido extinta.

Vale notar que a própria dinastia Safávida tem sua origem numa tarica sufi (fundada no séc. XIV). Mas, seus dirigentes foram aos poucos se irritando com as injustiças e erros do poder temporal, e decidiram não se conformar mais em deterem apenas a autoridade espiritual, e passaram a reivindicar igualmente 
o poder temporal. Foram os Safávidas que, a partir do início do séc. XVI, tornaram o Xiismo a religião oficial da Pérsia.

O regime estabelecido pela revolução liderada por Khomeini no Irã ao final do século XX passou a reprimir os sufis e suas instituições - a partir de então, algumas das principais figuras místicas persas se exilaram no exterior, caso de S. H. Nasr, hoje professor na Universidade George Washington, nos EUA, e do líder dos Nimatullahi, Javad Nurbakhsh (hoje falecido), e outros dirigentes, que emigraram para o Ocidente, onde a ordem Nimatullahi criou centros sufis e atraiu seguidores na Europa e nos EUA.

\section{Uma tarica do século XX, a Alawyiah}

O xeique Alawi foi um dos últimos grandes representantes do Sufismo nos Tempos Modernos. Ele é considerado o qutb (o "polo espiritual" do Islã) da primeira metade do século XX. A tarica Alawyiah foi estabelecida por ele em 1914, em Mostaganem, Argélia, em homenagem ao califa Ali, que surgiu numa visão ao xeique.

A Alawyiah foi uma das primeiras ordens sufis a estabelecer azóias na Europa ocidental; desde a década de 1920 que há registro de atividade da tarica em Paris e Marselha, na França, e Cardiff, no País de Gales. O próprio xeique Alawi visitou a Europa duas vezes, uma para a inauguração da grande mesquita de Paris, em 1926, e outra para orientar seus discípulos estabelecidos no Velho Continente.

Renomado por seu discernimento, sua intensa espiritualidade e sua visão universalista - o xeique tinha compreensão e abertura para outras tradições, especialmente a cristã. Ele apreciava em particular os Evangelhos e as Epístolas de São Paulo. O célebre monge católico trapista Thomas Merton anotou em seu diário: "O xeique Alawi é uma das mais profundas expressões da via mística em nosso tempo". ${ }^{17}$

Quando vivia no Cairo (entre 1930 e 1951), René Guénon tomou conhecimento das ideias e da personalidade do xeique Alawi, e recomendou ao então jovem Frithjof Schuon que travasse contato pessoal com ele. Coisa que Schuon fez em 1933, viajando a Mostaganem, na Argélia, onde ele permaneceu por quase quatro meses e onde ainda hoje está localizada a azóia central da tarica.

Defensor inteligente do Islã espiritual e tradicional, o xeique Al-Alawi foi um crítico do extremismo fundamentalista, como exemplificado pela "Irmandade Muçulmana", fundada no Egito, em 1928, e que costuma criticar o Sufismo como "não islâmico" e "supersticioso". Ao literalismo dos adeptos

\footnotetext{
${ }^{17}$ Citado em: Merton \& Sufism: The untold history (EUA, Fons Vitae, 1991).
} 
desta corrente fundamentalista, ele respondia que "mais vale uma oração sem ajoelhar (parte compulsória da prece canônica islâmica), do que se ajoelhar sem alma". Alawi, de outra parte do espectro filosófico, tampouco poupava o modernismo secularista e ocidentalizante, como tipificado pela Turquia de Atatürk. Para o sufi magrebino, as respostas aos desafios do secularismo e do fundamentalismo modernos estão nas doutrinas e práticas da espiritualidade tradicional.

Alawi começou sua trajetória no sufismo como adepto de uma tarica marroquina conhecida por práticas exóticas como encantar serpentes. Um dia, metido nestas práticas, o jovem Alawi se encontrou com um moqqadem da tarica Darqawia, que lhe diz que vai lhe mostrar uma serpente muito maior e cujo veneno era mais mortal do que a daquela cobra que ele, Alawi, estava a ponto de hipnotizar. O jovem sufi lhe pergunta onde ela estava, e o moqqadem responde que ele se referia ao ego, à alma carnal (nafs), e que se conseguisse domar esta "víbora", era sinal de que ele era um verdadeiro sábio. ${ }^{18}$

Um dos aspectos mais marcantes do método espiritual do xeique Alawi é o lugar absolutamente central concedido à invocação do Santo Nome, especialmente num contexto de retiro espiritual.

Com o exemplo vivo de sabedoria e espiritualidade do xeique Alawi, concluímos esta introdução aos ensinamentos e práticas de Ordens Sufis atuantes no mundo contemporâneo, mundo que arqueja sob a tirania do "politicamente correto", uma forma absolutista de relativismo intelectual e moral que asfixia a alma e obnubila a mente de muitos. Ainda assim, a mensagem de verdade, serenidade e virtude propagada pelas Ordens Sufis segue iluminando e inspirando, a partir do mundo do Islã, o caminho dos homens e mulheres espiritualmente alertas deste século XXI.

${ }^{18}$ Cf. Éric Geoffroy, in: revista Ultreia, p. 22 (França, Hiver, 2016). 